\section{Contested relationships between biodiversity conservation and poverty alleviation}

The development assistance community has collectively identified poverty alleviation as one of the Millennial Development Goals. Ambitious, hopeful targets have been set to redress one of the most vexing problems of our time, and the United Nations General Assembly called on 18 September 2000 for a halving of the number of people living in extreme poverty by 2015. With this declaration of a new global war on poverty, the United Nations system challenges the human community on behalf of the world's poor. However, achieving the goal of liberating half the world's poor from their poverty by 2015 will either mark the true beginning of sustainability or the end of biodiversity at the hands of the best-intentioned policies. Without reshaping poverty alleviation strategies, biodiversity will pay the price for development yet again, and the human "subsidy from nature" (Anderson et al., 1991) will tax biodiversity to death.

This far-reaching and laudable social goal for poverty reduction is being debated within the development community itself by development advocates, but missing in this dialogue are the implications of traditional poverty alleviation strategies for another millennial priority, the conservation of biodiversity. In fact, biodiversity has all but disappeared from the global dialogue on sustainable development. Even the most eminent spokesman of development and freedom, Amartya Sen, scarcely mentions biodiversity in his otherwise compelling proposals for the poor (Sen, 1999).

The renewed focus on poverty alleviation without biodiversity conservation is concomitant with a shift of interest and funding away from biodiversity conservation programmes and objectives. Compare the agenda and results of last year's World Summit on Sustainable Development in Johannesburg with the 1992 World Summit on Environment and Development in Rio de Janeiro. Prior to 1992, sustainable development married economic improvement to conservation practice, however imperfectly. Frustrated by the floundering Rio process during the 1990s, developmentalists shifted the sustainability argument to read that poverty alleviation will itself achieve many conservation goals. According to this view, poverty alleviation does not abandon conservation, but funds different means to achieve the same ends (Bojo et al., 2001). This perspective mirrors an earlier, equally flawed argument that clear property rights would produce conservation. In fact, both poverty alleviation and property rights only yield conservation when tied to an explicit conservation strategy (Naughton \& Sanderson, 1995).

Current poverty alleviation perspectives resuscitate economic development strategies of the 1950s, in which the gains in development were explained by greater access to markets, infrastructure support, and economies of scale. In a world far more rural than today's, development emphasized significant increases in productivity of labour, land and capital. It meant agricultural credit, water, improved seed and inputs, and rationalization of labour and capital in primary commodities (Meier, 1984). Now, in an increasingly urban world, the bulk of the world's rural poor struggle to increase productivity, pushed by pressures from urban consumption. With the exception of the poorest rural countries of equatorial Africa and South-east Asia, poverty alleviation today means access to the means of consumption in urban communities, with much greater demand on a reduced agriculture and a declining agricultural population. With a closed agricultural frontier in much of the world, minimal unclaimed fresh water, high levels of land degradation, and an increasingly skewed rural-urban income distribution, the world will demand that fewer and poorer agriculturalists produce more commodities with less inputs for a rapidly growing consumer population. To call this model sustainable requires great feats of imagination. In fact, the global community risks repeating the experience of the post-war developmentalists. It is no less true now than 50 years ago that "There is a real danger of the macro-models of economic development 'running on their own steam' without any reference to the fundamental human problems of backwardness." (Myint, 1954).

The tremendous gains in human welfare in the postwar decades cannot be undervalued. But neither can the huge environmental costs of this economic development. Accordingly, the sustainable development push of the 1980s and 1990s, with its explicit conservation objectives, had great potential to marry human possibilities to conservation needs (Lele, 1992; Redford \& Sanderson, 1992). Without changing the economic premises of development, the global community risks traveling back 
to the future, by recycling strategies from a bygone era. The battlefields in this contested relationship between biodiversity and economic growth are the tropical forests of Equatorial Africa, Indonesia and Amazonia, where mining biodiversity means short-term gains in forestry sector growth but long-term detriment to the world's tropical biota. Likewise, the river basins of South-east Asia are now captured by giant multilateral schemes such as the Mekong River Basin development programme, charged with developing the region but burdened by massive ecological dislocation.

In its new incarnation, poverty alleviation has largely subsumed or supplanted biodiversity conservation. This trend has gone largely unnoticed, but poses a significant threat to conservation objectives. Yet conservation organizations could actually help poverty alleviation through conservation by working with small-scale, low-output producers on the ecological frontier. This prospect complements Millennium Goals and can be important to true long-term poverty alleviation. Human-oriented, smallscale conservation could be as important to poverty alleviation as micro-lending is to development finance: not readily scalable, not changing aggregate national income figures, but also not irresponsible in resource use, and extremely valuable to those who will not benefit from traditional development strategies.

What would a more successful poverty alleviation strategy look like, and how can conservation organizations help? Millennium Goals must include the complicated interactions between biodiversity and poor people. Far more attention needs to be paid to rural poverty (IFAD, 2001), with specific cautions. Much agricultural development can be consistent with both human sustainability and conservation of biodiversity not requiring revolution, but rather careful attention to many ideas that receive more lip service than true devotion:

- Freezing the expansion of the agricultural frontier and working to recover degraded lands. Much can be done to enhance the use of lands already converted for human use.

- Scaling down rural development, emphasizing lowoutput producers.

- Redesigning animal husbandry to emphasize indigenous breeds, low herd densities, and husbandry techniques most beneficial to the poor.

- Sustaining fisheries through small-scale common property arrangements.

There is another, broader opportunity than refinements in primary commodity production. That is to think of conservation in the most remote and fragile ecosystems as partnership opportunities for poverty alleviation. Effective, long-term field conservation in small com- munities in fragile ecosystems can and does sustain biodiversity, as well as supporting vanishing folk ways, languages and communities (Redford \& Padoch, 1991). But such complementarity can only be achieved if we respect the strengths and weaknesses of both conservation and poverty alleviation efforts and the tradeoffs inherent in integrating them. Calls for "pro-poor conservation" (DFID, 2002) that ignore these tradeoffs will end up in failure, with both the poor and biodiversity suffering.

The millennial challenge is not to divert development and poverty alleviation from the needs of natural systems, nor to ratchet up the demand by human populations on primary commodity output. Even without bolder calls for changing income distribution to favor the poor, more creative and integrative poverty alleviation in the countryside could result from a more successful marriage of biodiversity conservation and rural development. The single requirement is a dedication to creating the kinds of partnerships between conservationists and developmentalists that eluded the Rio process and virtually vanished in Johannesburg.

Steven E. Sanderson and Kent H. Redford

Wildlife Conservation Society

Bronx, N.Y. 10460, USA

E-mail: ssanderson@wcs.org

\section{References}

Anderson, A., May, P. \& Balick, M. (1991) The Subsidy from Nature. Columbia University Press, New York, USA.

Bojo, J., Bucknall, J., Hamilton, K., Ishor, N., Kraus, C. \& Pillai, P. (2001) Environment: Poverty Reduction Strategy Papers. World Bank, Washington, DC, USA.

Department for International Development (DFID) (2002) Wildlife and Poverty Study. Livestock and Wildlife Advisory Group, Department for International Development, UK.

International Fund for Agricultural Development (IFAD) (2001) Rural Poverty Report. International Fund for Agricultural Development, Rome, Italy.

Lele, S.M. (1992) Sustainable development: a critical review. World Development, 19, 607-621.

Meier, G.M. (1984) The Formative Period. In Pioneers in Development (eds G.M. Meier \& D. Seers), pp. 3-22. Oxford University Press, New York, USA.

Myint, H. (1954) An interpretation of economic backwardness. Oxford Economic Papers, 6, 132-163.

Naughton, L. \& Sanderson, S. (1995) Property, politics and wildlife conservation. World Development, 28, 1265-1275.

Redford, K. \& Padoch, C. (1991) Conservation of Neotropical Forests: Building from Traditional Resource Use. Columbia University Press, New York, USA.

Redford, K. \& Sanderson, S. (1992) The brief barren marriage of biodiversity and sustainability. Bulletin of the Ecological Society of America, 73, 36-39.

Sen, A. (1999) Development as Freedom. Knopf, New York, USA. 